\title{
PENDIDIKAN ISLAM DAN MADRASAH
}

\section{Oleh : Kafrawi ${ }^{77}$}

\begin{abstract}
Abstrak
Pendidikan Islam mengalami perkembangan yang pesat dalam menyebarkan Islam melalui berbagai cara termasuk diperankan oleh cendikiawan muslim dan lembaga-lembaga Islam di dunia dan tak terlepas juga berbagai lembaga mulai yang lain melalui pesantren, masjid sampai juga madrasah. Faktor terbentuknya sendiri pendidkan islam Indonesia tak terlepas dari keadaan bangsa Indonesia sendiri sampai faktor keadaan luar negeri. Madrasah salah satu lembaga pendidikan islam memberikan warnanya tersendiri dari sejarah terbentuknya pendidikan Madrasah di Indonesia, terciptanya Madrasah yang unggul yang bisa bersaing di zaman sekarang ini, dan peluang serta tantangan Madrasah dalam menghadapi era globalisasi.
\end{abstract}

\section{Kata Kunci : Pendidikan Islam, Madrasah}

\section{Pendahuluan}

Sejalan Islam masuk di Indonesia dan berkembang pengaruhnya yaitu dengan munculnya kerajaan Islam, pendidikan Islam pun berkembang mengikuti irama dan dinamika Islam tersebut. Dimanapun ada komunitas Islam, disana ada aktivitas pendidikan Islam yang dilaksanakan sesuai dengan situasi dan kondisi di tempat mereka berada. Hal demikian juga terlihat dari terbentuknya lembaga seperti mesjid, surau, pondok pesantren, madrasah, perguruan tinggi Islam, dan juga majelis ta'lim.

Jurnal ini membahas mengenai pengertian Madrasah, lahirnya pendidikan Madrasah di Indonesia, bagaimana menciptakan Madrasah yang unggul di era sekarang ini, dan bagaimana tantangan serta peluang Madrasah di era modern tersebut. Untuk menjawab tantangan itu, lahirlah

${ }^{77}$ Dosen Tetap Program Studi Pendidikan Agama Islam STAI Auliaurrasyidin Tembilahan Kabupaten Indragiri Hilir Propinsi Riau.

72 
Pada saat itu Islam telah berkembang secara luas dalam berbagai ilmu pengetahuan, dengan berbagai macam aliran atau mazhab dan pemikirannya. Pembidangan ilmu pengetahuan tersebut, bukan hanya meliputi ilmu yang berhubungan dengan al-Qur'an dan Hadits, seperti ilmu al-Qur'an, Hadits, Fiqih, ilmu kalam maupun ilmu Tasawuf, tetapi juga bidang filsafat, astronomi, kedokteran, matematika dan berbagai bidang ilmu alam dan kemasyarakatan.

Meskipun madrasah sebagai lembaga pendidikan dan pengajaran di dunia Islam baru muncul sekitar abad ke-5 $\mathrm{H}$ berarti awal sejak perkembangannya, Islam tidak mempunyai lembaga pendidikan dan pengajaran. Islam datang dan mewarisi dari bangsa Arab masa itu, ternyata jauh sebelum itu, yaitu pada zaman pemerintahan Bani Umaiyah ${ }^{81}$, umat Islam sudah mempunyai lembaga pendidikan Islam yang disebut " $k u t t a b " 82$. Para guru yang mengajar di Kuttab ini pada mulanya adalah orang-orang non muslim, terutama orang-orang Yahudi dan Nasrani. Karena itulah, bagi umat Islam, pengajaran kuttab itu hanya sebagai tempat belajar keterampilan

\footnotetext{
${ }^{80}$ Madrasah Nizhamiyah Baghdad adalah Madrasah Nizhamiyah yang paling utma dan penting. Tokoh-tokoh ulama muslimin antara abad ke-5 dan ke-9 Hijriah banyak belajar di situ. Jumlah mahasiswanya mencapai 6.000 orang, Di antara mereka, ada putra pembesar tertinggi kerjaan dan ada pula putra buruh paling miskin. Semua mahasiswa di situ belajar dengan gratis, bagi siswa yang miskin, bahkan lebih dari itu. Mereka mendapat tunjangan tertentu yang diambil dari dana khusus untuk keperluan tersebut. Baca Buku Mustafa Husni As-Siba'i. Khazanah Peradaban Islam. (Bandung: Pustaka Setia). h. 191

${ }^{81}$ Bani Umaiyah didirikan oleh Muawiyah bin Abi Sofyan bin Harb bin Umaiyah, telah mengembangkan gerakan-gerakan ilmiah yang berpusat di Kufah dan Basrah di Irak dalam bidang keagamaan, sejarah, dan filsafat. Dalam bidang pertama dijumpai ulama-ulama seperti Hasan al-Basri, Ibnu Syihab az-Zuhri dan Wasil bin Ata, dan Khalid bin bin Yazid bin Mu'awiyah adalah seorang orator dan penyair sekaligus orang yang pertama yang menerjemahkan buku-buku tentang astronomi, kedokteran dan kimia. Baca Buku Yusrisun, Mohd. Rum, dkk. Pendidikan Agama Islam untuk kelas $x$ SMA/SMK.(Pekanbaru: Yolia). h. 93-95

${ }^{82}$ Kuttab atau Maktab berasal dari kata Kataba artinya menulis atau tempat menulis, jadi Kuttab adalah tempat belajar menulis. Dalam Ensiklopedia dijelaskan bahwa Kuttab adalah sejenis tempat belajar yang lahir di dunia Islam di Tanah Arab, namun belum dikenal yang Pada awalnya berfungsi sebagai tempat memberikan pelajaran menulis dan membaca bagi anak-anak. Baca Buku Suwito dan Fauzan.Sejarah Sosial Pendidikan Islam, (Jakarta: Kencana Prenada Media. 2005). h. 11
} 
membaca dan menulis saja, sedangkan pengajaran al-Qur'an dan dasar agama Islam diberikan dan diajarkan di mesjid oleh para guru khusus. Selanjutnya, untuk kepentingan pengajaran menulis dan membaca bagi anak-anak, yang sekaligus juga memberikan pelajaran al-Qur'an dan dasardasar pengetahuan agama Islam, diadakanlah kuttab-kuttab yang terpisah dari mesjid agar anak-anak tidak menggangu ketenangan dan kebersihan mesjid. Lahirnya madrasah-madrasah di dunia Islam, pada dasarnya merupakan usaha pengembangan dan penyempurnaan zawiyah tersebut, dalam rangka menampung pertumbuhan dan perkembangan dan jumlah pelajar yang semakin meningkat. ${ }^{83}$

Para Sarjana menyebut Madrasah sebagai "Higher Learnig in Islam" atau College. Sebutan ini menunjukkan bahwa kajian yang diselenggarakan di Madrasah lebih tinggi tingkatannya dibandingkan dengan Kuttab yang merupakan pendidikan dasar. Madrasah merupakan lembaga pendidikan dengan fokus kajian ajaran Islam yang berdasarkan wahyu yang mentransmisikan keilmuan dengan metode tradisional, bahkan halaqah. ${ }^{84}$ Adapun universitas merupakan lembaga pendidikan modern yang bertujuan melakukan penyelidikan bebas berdasarkan nalar (universitas litteratum et atrium liberalium atau universitas magiatorum et scholarum.$^{85}$

83 Hasbullah. Sejarah Pendidikan Islam di Indonesia: lintasan sejarah Pertumbuhan dan Perkembangan. (Jakarta: RajaGrafindo Persada. 1999). h. 160-162

${ }^{84}$ Halaqah adalah sebuah istilah yang ada hubungannya dengan dunia pendidikan, khususnya pendidikan atau pengajaran Islam (tarbiyah Islamiyah). Istilah halaqah (lingkaran) biasanya digunakan untuk menggambarkan sekelompok kecil Muslim yang secara rutin mengkaji ajaran Islam. Jumlah peserta mereka dalam kelompok kecil tersebut berkisar antara 3-12 orang. Mereka mengkaji Islam dengan manhaj (kurikulum) tertentu. Biasanya kurikulum tersebut berasal dari murabbi/naqib yang mendapatkannya dari jamaah (organisasi) yang menaungi halaqah tersebut. Di beberapa kalangan, halaqah disebut juga mentoring, ta'lim, pengajian kelompok, tarbiyah atau sebutan lainnya. (Ummu Hasnaa fajriah Nur, 2018. https://pendidikansunnah.wordpress.com).

${ }^{85}$ Arief Subhan. Lembaga Pendidikan Islam Indonesia Abad ke-20: Pergumulan antara Modernisasi dan Identitas. (Jakarta Prenada Media Group. 2012). h. 39 


\section{Lahirnya Madrasah di Indonesia}

Terlepas dari kenyataan historis di atas, madrasah di Indonesia berbeda dengan madrasah yang berkembang di Timur Tengah. Madrasah di Indonesia dipandang sebagai perkembangan lebih lanjut atau pembaruan dari lembaga pendidikan pesantren dan surau. Sementara itu, madrasah di Timur Tengah pada masa pertengahan, menurut Makdisi, mirip dengan lembaga pesantren ${ }^{86}$ di Indonesia, terutama dilihat dari unsur-unsur di dalamnya. Sebagaimana elemen dalam madrasah yang terdiri dari masjid, asrama, dan ruang belajar, pesantren pun merupakan sebuah kompleks yang memiliki sebuah masjid, pondok, dan tempat belajar. Selain itu, madrasah abad pertengahan mempunyai syaikh atau profesor yang diposisikan sebagai pemegang otoritas. Di Pesantren, fungsi yang sama dipegang oleh figur kiyai. Karenanya, sejarah ${ }^{87}$ tumbuhnya madrasah di Indonesia memiliki latar belakang sejarahnya sendiri dan ini dapat dikembalikan pada situasi abad ke-20, Walaupun dimungkinkan ini sebagai konsekuensi dari pengaruh intensif pembaruan pendidikan Islam di Timur Tengah.

Kehadiran lembaga-lembaga pendidikan Barat dalam bentuk sekuler yang dikembangkan penjajah merupakan tantangan tersendiri akan eksistensi pendidikan Islam klasik di negara-negara Islam. Problem yang sama, sebagaimana di Mesir pada abad ke-19, juga dirasakan di Asia

${ }^{86}$ Pesantren sendiri menurut pengertian dasarnya adalah "tempat belajar para santri", sedangkan yang terbuat dari bamboo. Disamping itu, kata "pondok" juga berasal dari bahasa Arab "Fundaq" yang berarti hotel atau asrama.Baca Buku Enung K Rukiati dan Fenti Hikmawati. Sejarah Pendidikan Islam di Indonesia. (Bandung:. Pustaka setia. 2006) h.. 103

${ }^{87}$ Terma "sejara" berasal dari bahasa Arab, yaitu berasal dari kata "Syajarotun", yang artinya "pohon". Jika telaah secara sistematis, memang sejarah hampir sama dengan pohon, yaitu mempunyai cabang dan ranting, bermula dari sebuah bibit pohon kemudian tumbuh dan berkembang, lalu layu dan tumbang. Semakna dengan bahasa Arabnya, kata sejarah dalam bahasa Indonesia berarti "silsilah","asal-usul (keturunan)", dan "kejadian dan peristiwa yang benar-benar terjadi pad masa lampau". Ading Kusdiana. Sejarah dan Kebudayaan Islam periode Pertengahan. (Jakarta: Pustaka Setia. 2013. h. 1 
Tenggara $^{88}$, khususnya Indonesia. Sampai munculnya gerakan pembaruan pada akhir abad ke-19, respons atas tantangan itu lebih bersifat isolatif, bahkan cenderung defensif. Pendidikan Islam mengasingkan diri dari pengaruh pendidikan modern. Pendidikan Islam hanya mengajarkan ilmu agama dan menolak mengajarkan ilmu umum.

Lahirnya madrasah pada awal abad ke-20 dapat dikatakan sebagai perkembangan baru di mana pendidikan Islam mulai mengadopsi matapelajaran non-keagamaan. Hal ini dimungkinkan karena gerakan pembaruan muncul dengan semangat yang sangat progresif seperti halnya di Timur Tengah di bawah pengaruh Jamaluddin aJ-Afghani dan Muhammad Abduh.

Latar belakang kelahiran madrasah sendiri bertumpu pada dua faktor penting: (1) pendidikan Islam tradisional kurang sistematis dan kurang memberikan kemampuan pragmatis yang memadai, dan (2) laju perkembangan sekolah-sekolah model Belanda di kalangan masyarakat cenderung meluas dan membawa watak sekularisme sehingga harus diimbangi dengan sistem pendidikan islam yang rnemiliki model dan organisasi yang lebih teratur dan terencana.

Penting untuk dicatat, bahwa tahap-tahap perintisan pembentukan madrasah itu sudah terlebih dahulu dilakukan oleh sejumlah tokoh dengan membuat sekolah ala Belanda dengan muatan tambahan dalam bidang ilmuilmu keagamaan, khususnya tulis-baca Al-Quran. Dalam pemikiran tokohtokoh ini, perlu ditempuh cara kombinasi antara sistem pendidikan tradisional yang menekankan ilmu-ilmu agama dengan sistem pendidikan

${ }^{88}$ Asia tenggara adalah sebuah kawasan di benua Asia bagian tenggara. Kawasan ini mencakup Indo Cina dan Semenanjung Malaya serta kepulauan di sekitarnya. Asia tenggara berbatasan dengan Republik Rakyat Cina di sebelah utara, Samudera Pasifik di timur, samudera Hindia di selatan, dan samudera Hindia, Teluk Benggala, dan anak benua India di barat. Asep Ahmad Hidayat, Samsuddin, dkk. Studi Islam di Asia Tenggara. (Bandung: Pustaka Setia. 2013). h. 1. 
modern (Belanda) dengan matapelajaran-matapelajaran umum seperti membaca, rnenulis, berhitung, bahasa, ilmu pengetahuan alam, ilmu pengetahuan kebudayaan, dan kererampian administrasi. Metode pengajarannya pun direkayasa sedemikian rupa sehingga lebih efektif sesuai dengan tingkat perkembangan masyarakat. Di antara tokoh ini adalah K.H. Ahmad Dahlan yang telah mendirikan sekolah Islam 'MULO met de Qur of di Yogyakarta. Kemudian disusul dengan sekolah-sekolah Islam lain yang dapat disebut menurut istilah teknis dalam pendidikan Islam.

Usaha untuk mendirikan lembaga pendidikan Islam sebanding dengan pendidikan ala Belanda dalam menjadi agenda bagi hampir semua organisasi dan gerakan Islam Indonesia. Selain Muhammadiyah ${ }^{89}$, organisasi Islam lain, seperti NU, Jami'at al-Khair ${ }^{90}$, Persatuan Umat Islam, Persatuan Islam $^{91}$, al-Irsyad ${ }^{92}$, al-Wasliyah, dan Persatuan Tarbiyah Islamiyah memiliki bagian atau seksi khusus dalam rangka pendirian madrasah-madrasah di berbagai daerah. Dengan corak masing-masing yang

${ }^{89}$ Organisasi ini didirikan di Yogyakarta ini adalah Muhammadiya. Pada tanggal 18 November 1912 bertepatan dengan tanggal Zulhijjah 1330 H, oleh Kyai Haji Ahmad Dahlan atas saran yan diajukaan oleh murid-muridnya dan beberapa orang anggota Budi Utomo untuk mendirikan suatu lembaga pendidikan yang bersifat permanen. Baca Zuhairini. Sejarah Pendidikan Islam. (Jakarta: PT. Bumi Aksara. 2010). h. 171

${ }^{90}$ Organisai yang lebih dikenal dengan nam Jami'at Khair ini didirikan di Jakarta pada tanggal 17 Juli 1905. Anggota organasisai ini mayoritas orang-orang Arab, tetapi tidak menutup kemungkinan untuk setiap Muslim menjadi anggota tanpa diskrimanasi asal-usul. Ibid. 159.

${ }^{91}$ Persatuan Islam (persis) didirikan di Bandung pada permulaan tahun 1920-an ketika orang-orang Islam di daerah lain telah lebih dahulu maju dalam berusaha untuk mengadakan pembaharuan dalam agama. Bandung kelihatan agak lambat memulai pembaharuan ini dibandingkan dengan daerah-daerah lain, sungguhpun Sarekat Islam telah beroperasi di kota ini semenjak tahun 1913. Kesadarn tentang keterlambatan ini merupakan sebuah cambuk untuk mendirikan sebuah organisasi. Ibid. 186.

${ }^{92}$ Pada tahun 1914nberdirilah perkumpulan Al-Irsyad perkumpulan Al-Islah wal Irsyad, kemudian terkenal dengan sebutan Al-Irsyad, yang terdiri dari golongan-golongan Arab bukan Alawi. Tahun 1915 berdirilah sekolah Al-Irsyad yang pertama di Jakarta, yang kemudian disusul oleh beberapa sekolah dan pengajian yang lain yang sehaluan dengan itu. Ibid. 162. 
berbeda, ini menandai satu perkembangan pendidikan Islam yang tidak terbatas pada pengajaran ilmu agama.

Dalam salah satu dokumen disebutkan bahwa tugas bagian pendidikan di lingkungan Departemen Agama itu meliputi: (1) memberi pelajaran agama di sekolah negeri partikular, (2) memberi pengetahuan umum di Madrasah, dan (3) mengadakan Pendidikan Guru Agama (PGA) dan Pendidikan Hakirn Islam Negeri (PHIN). Tentu saia, pada masa ini, penyelenggaraan madrasah mendapat subsidi dan bimbingan dari Departemen Agama.

Upaya membenahi madrasah terus digulirkan oleh Departemen Agama Pada 1975 telah ditandatangani Surat Keputusan Bersama (SKB) ${ }^{93}$ Tiga Menteri: Menteri Agama, Menteri Pendidikan dan Kebudayaan, dan Menteri Dalam Negeri No. 6 tahun 1975. Dalam bab II pasal 2 disebutkan bahwa: a) ljazah Madrasah dapat mempunyai nilai yang sama dengan ijazah sekolah umum yang seringkat, b) Iulusan madrasah dapat melanjutkan ke sekolah umum setingkat lebih atas. Namun, konsekuensinya madrasah harus mengubah kurikulumnya dengan $70 \%$ pelajaran umum dan hanya $30 \%$ pendidikan agama.

SKB Tiga Menteri tersebut dapat dianggap sebagai tonggak sejarah modernisasi madrasah. SKB tersebut dapat disebut sebagai titik awal penyelenggaraan madrasah secara lebih modern. SKB tiga Menteri

${ }^{93}$ Surat Kepurusan Bersama (SKB) Tiga Menteri diawali dengan keluarnya Surat Keputusan Presiden No. 34 Tahun 1972 tentang tanggung Jawab Fungsional Pendidikan dan Pelatihan yang isinya:

1. Menteri Pendidikan dan Kebudayaan bertugas dan bertanggung jawab atas pembinaan pendidikan umum dan kejuruan.

2. Menteri Tenaga Kerja bertugas dan bertanggung jawab atas pembinaan dan latihan keahlian dan kejuruan tenaga kerja, bukan pegawai negeri.

3. Ketua Lembaga Administrasi Negara bertugas dan bertanggung jawab atas pembinaan pendidikan dan latihan khusus untuk pegawai negeri. Baca Haidar Putra Daulay. Sejarah Pertumbuhan dan Pembaruan Pendidikan Islam di Indonesia. (Jakarta: Kencana Prenadamedia Group. 2007). h. 108 
dapat dipandang sebagai pengakuan terhadap eksistensi madrasah dan sekaligus langkah strategis menuju tahapan integrasi madrasah ke dalam sistem pendidikan nasional yang tuntas. Dengan mengikuti pola penyelenggaraan madrasah seperti yang digariskan dalam SKB tersebut, ijazah madrasah tidak saja diakui oleh Departemen Agama, tetapi juga oleh Departemen Pendidikan dan Kebudayaan (kini Departemen Pendidikan Nasional) departemen-departemen lain. Ini dapat dipandang sebagai sisi positif yang menguntungkan madrasah.

SKB Tiga Menreri tersebut mempunyai kelemahan. Dengan komposisi kurikulum seperti yang ditetapkan dalam SKB itu, penguasaan terhadap ilmu agama bagi lulusan maadrasah menjadi berkurang. Pada gilirannya, ini dapat mendangkalkan penguasaan pengetahuan agama di masyarakat. Karena itu, banyak tokoh masyarakat-ulama dan ustad- dan pengelola pendidikan Islam, yang memang merupakan orang yang berurusan langsung dengan nasib madrasah, bereaksi sangat keras dan menyatakan menolak SKB Tiga Menteri. Tuduhan di alamatkan kepada A. Mukti menolak SKB Tiga Menteri, Ali, sebagai pejabat Menteri Agama (1972-1977) waktu itu yang ingin menghancurkan Iembaga pendidikan Islam. Kelemahan tersebut pada dasarnya sudah disadari oleh Mukti Ali sejak awal. Namun, target yang sebenarnya adalah bagaimana umat Islam mengakhiri dikotomi keilmuan ${ }^{94}$, ilmu keagamaan dan ilmu umum. Madrasah sebagai lembaga pendidikan, harus berperan untuk tujuan. itu, yakni menghapus dikotomi ilmu.

\footnotetext{
${ }^{94}$ Kata "dikotomi" berasal dari bahasa Inggris "dichotomy" yang artinya membedakan dan mempertentangkan dua hal yang berbeda. Kata yang dalam bahasa Inggrisnya "dichotomy" tersebut, digunakan sebagai serapan ke dalam bahasa Indonesia menjadi "dikotomi" yang arti harfiahnya dalam kamus Besar Bahasa Indonesia adalah pembagian atas dua kelompok yang saling bertentangan. Baca Buku Baharuddin, Umiarso, dan Sri Minarti.Dikotomi Pendidikan Islam: Historisitas dan Implikasi pada Masyarakat Islam. (Jakarta: Remaja Rodakarya.2011) h. 143-144
} 
Menyadari semakin surutnya pengetahuan agama lulusan madrasah sebagai dampak dari SKB tersebut, semakin berkembanglah jenis madrasah lain. Dalam rangka memudahkan pembinaan dan bimbingan Departemen Agama menetapkan dua jenis madrasah, Pertama, madrasah yang selain menetapkan pelajaran agama sebagai matapelajaran pokok, juga memasukkan matapelajaran umum dalam kurikulumnya. jenis Kedua adalah madrasah yang semata-mata mempelajari agama dan isi kurikulumnya semua pelajaran agama. Jenis madrasah yang kedua ini selanjutnya disebut Madrasah Diniyah. Pertumbuhan Madrasah Diniyah yang pada 1990-an berjumlah sekitar 22.000, mengekspresikan tuntutan aspirasi masyarakat agar anak-anak mereka mengenyam pelajaran dan pendidikan agama lebih banyak.

SKB Tiga Menteri 1975 yang dianggap sebagian masyarakat itu mempunyai banyak kelemahan, "disempurnakan" ketika Munawir Sjadzali menjabat sebagai MenteriAgama (1983-dan 1988-1993). Madrasah Aliyah dengan kurikulum yang bermuatan $70 \%$ pengetahuan umum dan $30 \%$ pengetahuan agama justru merugikan IAIN. Siswa-siswa lulusan Madrasah Aliyah dengan kurikulum demikian ternyata kurang siap untuk meneruskan pendidikan agama, termasuk lemahnya penguasaan bahasa Arab. Bentuk "penyempurnaan" ituadalah mengadakan pilot project Madrasah Aliyah Program Khusus (MAPK) dengan muacan kurikulum $70 \%$ pengetahuan agama $30 \%$ pengetahuan umum. Dengan struktur kurikulum semacam ini, konsekuensinya lulusan MAPK tidak dapat masuk ke perguruan tinggi umum, tapi mereka merupakan bibit unggul bagi IAIN.m Pada 1988, proyek MAPK dimulai dan untuk tahap pertama dibuka di lima lokasi: Padang Pajang (Sumarera Barat), Ciamis (Jawa Barat), DI Jogjakarta, Ujung Pandang (Sulawesi Selatan), dan Jember. Tahap kedua MAPK dibuka di lima kota lagi: Banda Aceh, Lampung, Solo, Banjarmasin, dan Mataram. 
Menarik untuk dicatat bahwa munculnya madrasah merupakan respons umat Islam terhadap model pendidikan Barat. Umat Islam berusaha menyintesiskan antara sistem pendidikan tradisional dengan pendidikan modern dalam bentuk madrasah. Pada masa ini, pendidikanagama masih menjadi prioritas. Ketika eksistensi madrasah ingin diakui sebagai bagian dari sistem pendidikan nasional, pendidikan agama hanya sekadar pelengkap untuk mempertahankan "ciri khas" sekolahIslam.

Kebijakan Mukti Ali yang ingin mengikis dikotomi keilmuan melalui madrasah tersebut, karena tidak diimbangi dengan perangkat pendukung di tingkat bawah, menjadikan kebijakan inijustru mementahkan mutu keilmuan lulusannya. Lulusan madrasah negeri pada umumnya tanggung dalam pengetahuan umum, dan juga dangkaI dalam penguasaan ilmu agama. Kondisi ini disadari dan direspons oleh pemerintah dengan membuka Mardrasah Khusus.

Pada dasarnya, dibukanya MAPK adalah upaya mengembalikan madrasah ke tujuan semula dengan beberapa penyempurnaan. MAPK juga dimaksudkan sebagai penyuplai utama mahasiswa dalam jenjang pendidikan tinggi Islam. Namun, jumlah MAPK yang sangat terbatas, dan tidak seimbang dengan jumlah Perguruan Tinggi Islam yang banyak, tujuan pendirian MAPK pun menjadi kurang maksimal. Kondisi madrasah yang dipandang sebagian masyarakat telah terjadi pergeseran keilmuan, ditanggapi dengan membentuk madrasah diniyahatau melestarikan lembaga pesantren sebagai tempat pendidikan keagamaan. Dengan demikian, terbentuklah banyak model pendidikan Islam, khususnya madrasah. ${ }^{95}$

\footnotetext{
${ }^{95}$ Nor Huda. Islam Nusantara: Sejarah Sosial Intelektual Islam di Indonesia. (Jogjakarta: AR-RUZZ MEDIA.2016). h. 389-399.
}

82 


\section{Menciptakan Madrasah Yang Unggul Di Era Sekarang}

Syarat menuju pengembangan madrasah unggulan antara lain ketersediaan tenaga pendidikan yang profesional, kelengkapan sarana dan prasarana, perlu ditangani dengan sistem manajemen profesional yang modern, transparan dan demokratis, dan adanya kurikulum yang sesuai dengan kebutuhan masyarakat dan tantangan dunia modern. Selain itu, madrasah juga perlu memberikan perhatian untuk senantiasa meningkatkan kualitas, mengembangkan inovasi dan kreativitas, membangun jaringan kerjasama (networking), dan memahami karakteristik pelaksanaan otonomi daerah.

Pada akhirnya, keunggulan sebuah madrasah akan sangat ditentukan oleh keberhasilan peserta didik (output dan outcome) yang memiliki prestasi yang membanggakan. Dalam konteks keberhasilan madrasah, maka keberhasilan tersebut tidak saja diukur dari nilai akademik yang tinggi, tetapi juga harus dilihat dari perilaku yang Islami (akhlaqul karimah).

Madrasah unggulan dimaksudkan sebagai center for excellence. Madrasah Unggulan diproyeksikan sebagai wadah menampung putra-putri terbaik masing-masing daerah untuk dididik secara maksimal tanpa harus pergi ke daerah lain. Dengan demikian terjadinya eksodus SDM terbaik suatu daerah ke daerah lain dapat diperkecil, dan sekaligus menumbuhkan persaingan sehat antara daerah dalam menyiapkan SDM mereka. Karena menjadi center for excellence anak-anak terbaik, maka kesempatan belajar di kedua jenis madrasah ini haruslah melalui proses seleksi yang ketat dan dengan berbagai kententuan lainnya. Madrasah ini diperkuat oleh keberadaan majelis madrasah yang juga memiliki peran penting dalam pengembangannya.

Madrasah unggul dikembangkan untuk mencapai keistimewaan dalam keluaran pendidikannya. Untuk mencapai keistimewaan tersebut, 
maka masukan, proses pendidikan, guru dan tenaga kependidikan, manajemen, layanan pendidikan, serta sarana penunjangnya harus diarahkan untuk menunjang tercapainya tujuan tersebut.

Dengan memerhatikan fakta-fakta yang ada, maka ciri-ciri madrasah unggul yang dapat diidentifikasi ialah (1) prestasi akademik dan nonakademik di atas rata-rata sekolah yang ada di daerahnya; (2) sarana dan prasarana dan layanan yang lebih lengkap; (3) sistem pembelajaran lebih baik dan waktu belajar lebih panjang; (4) melakukan seleksi yang cukup ketat terhadap pendaftar; (5) mendapat animo yang besar dari masyarakat, yang dibuktikan banyaknya jumlah pendaftar dibanding dengan kepasitas kelas; (6) biaya sekolah lebih tinggi dari sekolah di sekitarnya.

Kementerian Agama sebagai salah satu pelaksana program pendidikan sekolah telah mengembangkan beberapa jenis madrasah unggulan, yaitu: Madrasah Aliyah Keagamaan, Madrasah Tsanawiyah Terbuka, Madrasah Model, Madrasah Aliyah Unggulan dan Madrasah Aliyah Keterampilan. Pengembangan kelembagaan di lingkungan madrasah dan sekolah Islam tidak hanya berhenti pada beberapa jenis sekolah di atas, tetapi terus berkembang hingga saat ini. Wacana pengembangan sekolah terpadu dan bertaraf internasional yang saat ini banyak diminati merupkan bagian dari pengembangan lebih lanjut dari beberapa jenis lembaga pendidikan di atas.

Strategi perluasan dan pemerataan kesempatan pendidikan di madrasah difokuskan kepada pelaksanaan wajib belajar 9 tahun, bahkan di perkotaan sudah berkembang pada wajib belajar 12 tahun. Indikator kunci keberhasilan strategi ini antara lain adalah; (1) mayoritas penduduk berpendidikan minimal MTs diwujudkan oleh meningkatnya APK pada semua jenjang dan jenis madrasah, (2) meningkatnya budaya belajar yang ditunjukkan dengan meningkatnya angka melek aksara; dan (3) proporsi 
jumlah penduduk yang kurang beruntung yang mendapat kesempatan pendidikan semakin meningkat.

Strategi peningkatan layanan pendidikan di madrasah difokuskan pada upaya mencegah siswa agar tidak putus sekolah dan mempertahankan mutu pendidikan agar tidak semakin menurun. Indikator kunci keberhasilan implementasi stretegi ini adalah; (1) memperkecil angka putus sekolah di madrasah; (2) meningkatnya APK dan APM, baik MI dan MTs terutama bagi peserta didik yang kurang beruntung (miskin, tinggal di wilayah terpencil, broken home dan sebagainya); (3) mendorong kembali dan memfasilitasi siswa yang telanjur putus sekolah; (4) mempertahankan dan meningkatkan mutu proses kegiatan belajar dan mengajar di madrasah, termasuk penggunaan ICT dalam pembelajaran, meskipun dana yang terbatas.

Strategi peningkatan mutu dan relevansi pendidikan di madrasah difokuskan kepada pengembangan empat aspek yakni kurikulum, guru dan tenaga kependidikan lain, sarana pendidikan dan kepemimpinan madrasah. Dalam kaitan ini dilaksanakan pengembangan kurikulum berkelanjutan di semua jenjang dan jenis madrasah, dilakukan pembinaan profesi guru madrasah, dilaksanakan peningkatan pengadaan dan pendayagunaan sarana dan prasarana pendidikan di madrasah serta pengembangan kepemimpinan di madrasah yang berlandaskan prinsip manajemen berbasis madrasah.

Strategi pengembangan manajemen pendidikan madrasah berkenaan dengan upaya pengembangkan sistem manajemen madrasah sehingga secara kelembagaan madrasah memiliki kemampuan: (1) mengembangkan prakarsa dan kemampuan kreatif dalam mengelola pendidikan, (2) mengembangkan organisasi pendidikan madrasah yang lebih berorientasi profesionalisme, dan (3) layanan pendidikan yang semakin cepat, terbuka, adil, dan merata. 
Strategi pemberdayaan kelembagaan madrasah ditekankan kepada pemberdayaan madrasah sebagai pusat pembelajaran, pendidikan dan pembudayaan. Indikator kunci keberhasilannya antara lain adalah: (1) tersedianya madrasah yang semakin bervariasi dengan dukungan organisasi yang efektif dan efisien; (2) mutu dan sarana dan prasarana madrasah yang semakin meningkat dan iklim pembelajaran yang semakin kondusif bagi peserta didik. ${ }^{96}$

\section{Bagaimana Tantangan Dan Peluang Madrasah Di Era Globalisasi}

\section{Peluang}

Muslimin merupakan komunitas terbesar kedua yang ada di bumi ini. Tentu merupakan sebuah potensi yang sangat besar bila hal itu mampundigarap secara baik, baik dari segi kualitas maupun kuantitasnya. Lebih dari itu, jika dilihat, sebagian besar negara Muslim merupakan negara yang memiliki potensi alam yang sangat kaya. Sehingga dua potensi, yakni sumber daya manusia das umber daya alam, jika dipadukan secara simultan, maka akan menjadi sebuah kekuatan besar di dunia ini.

Semakin terbukanya cakrawala pemikiran di antara sebagian intelektual muslim, salah satunya ditandai dengan semakin banyaknya pelajar/sarjana Muslim yahg belajara di Barat, merupakan angin segar bagi upaya menemukan kejayaan masa lalu yang hilang. Salah satu hal yang perlu disoroti adalah gerakan-gerakan negara Islam seperti OKI atau Liga Arab, jika mampu mengoptimalisasikan pera, khusunya

${ }^{96}$ Agustini Buchari, Erni Moh. Saleh. Merancang pengembangan Madrasah Unggul. Diterbitkan Online Desember 2016. Journal of Islamic Education Policy. Vol.1, No.2, 95-112. 2016.h. 105-107. 
pencerahan dalam bidang pendidikan, akan memberikan kontribusi dan dampak yang cukup signifikan bagi masyarakt Islam dunia. ${ }^{97}$

\section{Tantangan}

Pertama, tantangan kemajuan ilmu pengetahuan dan teknologi, ${ }^{98}$ tidak dapat disangkal bahwa dunia ini masih saja dibagi kepada dua kelompok besar, yaitu negara-negara maju dan negara-negara berkembang. Negaranegara maju menjadiprodusen dari hasil-hasil kemajuan teknologi tersebut, sedangkan negar-negara berkembang menjadi konsumen. Dengan demikia, negara-negara berkembang akan menjadi negara yang bergantung kepada negara-negara maju. Negara-negara maju akan meraih keuntungan yang banyak dari penjualan hasil produksi mereka terhadap negara-negara berkembang.

Kedua, tantangan ekonomi, disebabkan negara-negara maju tumbuh menjai negara-negara kaya, maka laju perekonomian dunia pun akhirnya ditentukan pula oleh negara-negara maju, negar-negara berkembang karena kekurangan sumber daya manusia terampil, maka tidak bisa mengolah hasil dalam negeri mereka secara maksimal untuk mendapat nilai tambah, maka otomatis pula berpengaruh kepada penghasiolan negara tersebut.

Ketiga, tantangan culture (budaya). Persaingan budaya pun tidak bisa dihindari, dari berbagai hal yang berkenaan dengan gaya hidup, Hal. 169.

${ }^{97}$ Masduki Duryat. Paradigma Pendidikan Islam. (Bandung: Alfabeta. 2016).

${ }^{98}$ Tritarahadja (2005) menyatakan bahwa pendidikan serta ilmu pengetahuan dan teknologi memiliki kaitan yang sangat erat. Iptek menjadi bagian utama dalam isi pembelajan. Dengan kata lain bahwa pendidikan berperan sangat penting dalam pewarisan dan pengembangan Iptek. Iptek merupakan salah satu hasil dari usaha manusia untuk mencapai kehidupan yang lebih baik. Pada sisi lain, pada setiap perkembangan Iptek harus sering diakomodasi oleh pendidikan yakni dengan segera memasukkan hasil pengembangan iptek itu ke dalam bahan ajar. Baca Abdul Kadir. Dasar-Dasar Pendidikan. Jakarta: PrenadaMedia Group). h. 101. 
pandangan hidup, model pakaian, makanan, dan seterusnya akan muncul dia arena global. Di sini biasanya budaya-budaya yang berasal dari negara-negara maju akan mendominasi. ${ }^{99}$

\section{Kesimpulan}

Pendidikan Islam pada akhirnya mengalami perkembangan yang pesat dalam menyebarkan Islam diperankan oleh cendikiawan muslim dan lembaga-lembaga Islam di dunia dan juga tidak terlepas peran berbagai lembaga mulai dari pesantren, masjid sampai juga madrasah. Faktor terbentuknya sendiri pendidkan Islam Indonesia tak terlepas dari keadaan bangsa Indonesia sendiri sampai faktor keadaan luar negeri. Madrasah salah satu lembaga pendidikan islam memberikan warnanya tersendiri dari sejarah terbentuknya pendidikan Madrasah di Indonesia, terciptanya Madrasah yang unggul yang mampu bersaing di zaman sekarang, dan peluang serta tantangan Madrasah dalam menghadapi era globalisasi.

\section{Referensi}

Agustini Buchari, Erni Moh. Saleh. Merancang pengembangan Madrasah Unggul. Diterbitkan Online Desember 2016. Journal of Islamic Education Policy. Vol.1, No.2, 95-112. 2016.

Ading Kusdiana. Sejarah dan Kebudayaan Islam periode Pertengahan. (Jakarta: Pustaka Setia. 2013.

Asep Ahmad Hidayat, Samsuddin, dkk. Studi Islam di Asia Tenggara. Bandung: Pustaka Setia. 2013.

Baharuddin, Umiarso, dan Sri Minarti. Dikotomi Pendidikan Islam: Historisitas dan Implikasi pada Masyarakat Islam. Jakarta: Remaja Rodakarya. 2011.

\footnotetext{
${ }^{99}$ Haidar Putra Daulay dan Nurgaya pasa. Pendidikan Islam Dalam Lintasan Sejarah: kajian dari zaman pertumbuhan sampai kebangkitan.(Jakarta: Kencana PrenadaMedia Group. 2013). h. 198-199.
} 
Enung K Rukiati dan Fenti Hikamawati. Sejarah Pendidikan Islam di Indonesia. Bandung: Pustaka Setia. 2006.

Hasbullah. Sejarah Pendidikan Islam di Indonesia: lintasan sejarah Pertumbuhan dan Perkembangan. Jakarta: RajaGrafindo Persada. 1999.

Haidar Putra Daulay. Sejarah Pertumbuhan dan Pembaruan Pendidikan Islam di Indonesia. Jakarta: Kencana Prenadamedia Group. 2007

Haidar Putra Daulay dan Nurgaya pasa. Pendidikan Islam Dalam Lintasan Sejarah: kajian dari zaman pertumbuhan sampai kebangkitan.Jakarta: Kencana PrenadaMedia Group. 2013.

Nor Huda. Islam Nusantara: Sejarah Sosial Intelektual Islam di Indonesia. Jogjakarta: AR-RUZZ MEDIA. 2016.

Masduki Duryat. Paradigma Pendidikan Islam. Bandung: Alfabeta. 2016.

Suwendi. Sejarah dan pemikiran Pendidikan Islam. Jakarta: Raja Grafindo Persada. 2004.

Suwito dan Fauzan. Sejarah Sosial Pendidikan Islam. Jakarta: Kencana Prenada Media. 2005.

Yusrisun, Mohd. Rum, dkk. Pendidikan Agama Islam untuk kelas $x$ SMA/SMK.Pekanbaru: Yolia.

Zuhairini. Sejarah Pendidikan Islam. Jakarta: PT. Bumi Aksara. 2010. 